\title{
Phytochemical and Antimicrobial Screening of the Leaves of Crotalaria Lachnosema Against Staphylococcus Aureus, Salmonella Typhi, Escherichia Coli and Klebsiella Pneumoniae
}

\author{
Isah AbdulAzeez, Apampa Sulaiman Ayodeji* and Bello Danjuma \\ Department of Chemistry, Federal College of Education, Zaria, Nigeria
}

Received: 恝 September 17, 2018; Published: 眥 September 26, 2018

*Corresponding author: Apampa Sulaiman Ayodeji, Department of Chemistry, Federal College of Education, Zaria, Nigeria

\begin{abstract}
The leaves of Crotalaria lachnosema were freshly collected, dried under-shade and ground into powder. The ethanolic extract of the sample was obtained by cold extraction and was fractionated with solvent of varied polarity. The fractions were analyzed for their phytochemicals and screened antimicrobial against Staphylococcus aureus, Salmonella typhi and Escherichia coli. The phytochemicals were distributed among the test fractions. Tannins were found to be present in all the fractions and methanol fraction contains all the other tested phytochemicals except alkaloids and cardiac glucosides. The activities of the fractions were found to be more pronounced against $E$. coli than against the other test organisms.
\end{abstract}

Keywords: Phytochemical Screening; Antimicrobial; Crotalaria lachnosema; Staphylococcus aureus; Salmonella aureus; Salmonella typhi; Escherichia coli; Klebsiella pneumoniae

\section{Introduction}

For many centuries, man explores and utilizes the natural endowment offered by both the species of flora and fauna to provide the basic necessity of life such as clothing, shelter, food and indeed health care. Medicinal plants are the richest and commonest natural resource used in traditional medicine. Of the 250, 000 higher plant species on earth, more than 80,000 are medicinal[1]. Although plants had been priced for their medicine, flavoring effect and aromatic qualities for centuries, but the synthetic products of the modern age had for some time surpassed their importance. However, the blind dependence on synthetics is over and people are returning to the naturals with hope of safety and security [1]. The development of drug resistance in human pathogens against commonly used antibiotics has necessitated a search for new antimicrobial substances from other sources including plants [2]. Many reports have attested the efficacy of herbs against microorganisms, as a result, plant is one of the bedrocks of modern medicine to attain new principles [3]. The therapeutic properties of plants may not be unconnected to the variety of chemical substances biosynthesized by the plants as "secondary metabolites" that bring about definite physiological action in the human body. The most important of these bioactive constituents of plants are alkaloids, tannins,

flavonoids, saponins and etc. [4]. Presently many governments and major health institutions including the World Health Organization [5] have recognized, pharmacologically validated and improved many traditional herbal medicines and eventually integrated them in formal health care system [1]. Thus, in light of the evidence of rapid global spread of resistant clinical isolates, the need to find new antimicrobial agent is of paramount importance. However, the past record of rapid, widespread emergence of resistance to newly introduced antimicrobial agents, indicates that even new families of antimicrobial agents will have a short life expectancy [6]. For this reason, researchers are increasingly turning their attention to herbal products, looking for new leads to develop better drugs against MDR microbe strains [7].

Crotalaria lachnosema belongs to the family Fabaceace (Leguminoseae), sub-family Papilionoideae. It is a woody plant with a height of about $2 \mathrm{~cm}$ high. The plant is known as 'Fara birana' in Hausa, 'komp' in Yoruba, 'Ake dinwo' in Ibo and Birjibei in Fulani [8]. The genus Crotalaria is widespread in the tropics and subtropical region and has about 550 species [9]. C. lachnosema was found to be important in the treatment of scabies. The whole plant grounded and mixed with water are fed to animals to treat 
liver disease [8]. The presence of resins and balsams might support the use of the plant as emollient as well as for treatment of sore throat, rheumatism, wounds and burns. Since some basalms and resins has antiseptic properties [3]. Few species of Crotalaria have been assessed against some pests. For example, under greenhouse condition, $C$. retusa and $C$. juncea have been found to be resistant to attack by the nematode, Pratyylenchus zeae and also that $C$. retusa has shown a higher degree of resistance to attack by the nematode, Rotylenchus rnifirmis Linford and Olivera. It was also reported that, the non-polar extract of $C$. retusa contain some active ingredients for controlling flea beetle a pest on okro plant. So, could be useful in pest management [10].

\section{Materials and Methods}

\section{Sampling and Sampling Sites}

The leaves of Crotalaria lachnosema were freshly collected on $4^{\text {th }}$ July 2011 at an uncultivated land in Damanko village about $9 \mathrm{~km}$ west of Zaria main town, Zaria Local Government, Kaduna State. The plants were identified and authenticated by Mallam Umar Shehu Galla of the Herbarium unit, biological science, Ahmadu Bello Univesity, Zaria. The leaves of the plant were dried under-shade for seven days and ground into powder using clean pestle and mortar.

\section{Extraction and Fractionation of Plant Materials}

Cold extraction (Percolation) was adopted in this research, this is part of the appropriate measure to preserve constituents that may potentially be active and retain their original identities in the course of preparing the extract [11]. $200 \mathrm{~g}$ of the powdered plant sample was weighed and sucked in $1000 \mathrm{~cm}^{3}$ of ethanol for 14 days. The crude extract was prepared by decantation, filtration and concentration of the filtrate using Rota vapor machine (RVO) at $40^{\circ} \mathrm{C}$ and finally by drying the concentrated crude ethanol extract. Fractions of various degrees of polarities were obtained from ethanol extract by macerating the ethanol extract with different solvents in sequence starting with solvent of least polarity to the one of highest polarity [12]. For the fractionation, $30 \mathrm{~cm}^{3}$ of $\mathrm{n}$-hexane was poured into the beaker that contained the dried and gummy ethanol extract and stirred for 5 minutes and the liquid portion was then drained into another cleaned and empty beaker. This process was repeated until a clear solution was obtained at the end. The entire procedure was repeated with other solvents in the series; chloroform, ethyl acetate and methanol. Four fractions were thus obtained from the exercise and were labeled as followed: n-hexane fraction, chloroform fraction, ethyl acetate fraction and methanol fraction.

\section{Phytochemical Screening of Plant Sample}

The phytochemical analyses of the fractions were conducted by subjecting the fractions to different standard confirmatory tests. This is to determine the presence of certain phytochemical classes.
Test for Alkaloids: Each fraction (0.5g) was stirred with $5 \mathrm{ml}$ of 1 percent aqeous hydrochloric acid on a steam bath; $1 \mathrm{ml}$ of the filtrate was treated with a few drops of Mayer's reagent and a second $1 \mathrm{ml}$ portion was treated similarly with Dragendoff's reagent. Turbidity or precipitation with either of these reagents was taken as evidence for the presence of alkaloids in the extract being evaluated [13].

Test for Saponins: Each fraction (0.5g) was shaken with water in a test tube. Frothing which persists on warning confirmed the presence of saponins [14].

Test for Tannins: Each fraction $(0.5 \mathrm{~g})$ was stirred with $10 \mathrm{ml}$ of water. This was filtered, and ferric chloride reagent was added to the filtrate, a blue-black precipitate indicated the presence of tannins [15].

Test for Flavonoids: A portion of each fraction was heated with $10 \mathrm{ml}$ of ethylacetate over a steam bath for $3 \mathrm{mins}$. The mixture was filtered and $4 \mathrm{ml}$ of the filtrate was shaken with $1 \mathrm{ml}$ of dilute ammonia solution. A yellow colouration indicated the presence of flavonoid.

Test for Reducing Sugar: $1 \mathrm{ml}$ of each fraction was taken in five separate test tubes. These were diluted with $2 \mathrm{ml}$ of distilled water followed by addition of Fehling's solution $(A+B)$ and the mixtures were warmed. Brick red precipitate at the bottom of the test tube indicated the presence of reducing sugar [16].

Test for Cardiac Glycosides: $2 \mathrm{ml}$ of each fraction was placed in a sterile test tube. This was followed by adding $3 \mathrm{ml}$ of $3.5 \%$ iron III chloride $\left(\mathrm{FeCI}_{3}\right)$, then $3 \mathrm{ml}$ ethanoic acid. This gave a green precipitate and a dark colored solution respectively. Finally, concentrated $\mathrm{H}_{2} \mathrm{SO}_{4}$ was carefully poured down the side of the test tub e which resulted in the formation of brownish red layer, at the interface. This confirms the presence of cardiac glycosides.

\section{Antimicrobial Activity Test}

Agar disc diffusion technique was adopted for the sensitivity test as described by [17].

Preparation of Test Fractions' Concentration: Discs of about $6 \mathrm{~mm}$ diameter were punched from Whatman's No 1 filter paper using a paper puncher. Batches of 10 of the paper discs were transferred into vial bottles and sterilized in an oven at $140^{\circ} \mathrm{C}$ for 60 minutes. Stock solutions of $100 \mathrm{mg} / \mathrm{ml}$ of the fractions were prepared by dissolving $200 \mathrm{mg}$ of each fraction in $2 \mathrm{ml}$ of DMSO (Dimethyl sulphoxide). By means of $1 \mathrm{ml}$ sterile syringe, $0.1 \mathrm{ml}, 0.2 \mathrm{ml}, 0.5 \mathrm{ml}$ and $1.0 \mathrm{ml}$ were transferred into labeled vial bottles preoccupied with 10 paper discs from a stock solution of each fraction and the solution were subsequently diluted with $0.9 \mathrm{ml}, 0.8 \mathrm{ml}, 0.5 \mathrm{mland}$ $0.0 \mathrm{ml}$ (i.e. without dilution) of DMSO that correspondingly resulted to $1 \mathrm{mg} /$ disc, $2 \mathrm{mg} /$ disc, $5 \mathrm{mg} /$ disc and $10 \mathrm{mg} /$ disc concentration. 
The prepared concentrations of the test fractions in the labeled bottles were kept in refrigerator until required for use.

Preparation of Inoculum from the Test Micro-Organisms: Staphylococcus aureus, Salmonella typhi, Escherichia coli and Klebsiella pneumoniae that were sourced from Microbiology unit of Aminu Kano Teaching Hospital (AKTH) Kano, were the microorganisms used for the research. The identities of the microorganisms were confirmed by standard biochemical test [18]. The test organism was cultured and maintained in a nutrient agar slant at $4^{\circ} \mathrm{C}$. The organism was then inoculated into nutrient broth and incubated overnight at $37^{\circ} \mathrm{C}$ for $24 \mathrm{hrs}$. They were then diluted with normal saline until they give concentration of bacterial cells equivalent to $0.5 \mathrm{McF}$ arland standard of Barium sulphate solution $(1 \% \mathrm{v} / \mathrm{v})[19]$.

\section{Antibacterial Susceptibility Test (Bio Assay)}

A suspension of nutrient agar ( $28 \mathrm{~g}$ in $1000 \mathrm{ml}$ of distilled water) was prepared and autoclaved at $121^{\circ} \mathrm{C}$ for 15 mins according to the manufacturers' instruction. It was then carefully poured into sterile petri-dishes and allowed to solidify. The standardized inoculums of the bacteria were swabbed on the surface of the solid nutrient agar plates by means of sterile wire loop for the confluent growth of the bacteria. Four paper discs of $10 \mathrm{mg} /$ disc, $5 \mathrm{mg} /$ disc, $2 \mathrm{mg} /$ disc, $1 \mathrm{mg} /$ disc concentrations were taken from the prepared test fraction solutions and were carefully and aseptically placed on the inoculated surface of the nutrient agar and a positive control disc (Tetracycline $1 \mathrm{mg} /$ disc) was placed at the centre of the plate. The plates were incubated inverted at $37^{\circ} \mathrm{C}$ for 18 hours. The diameters of clear areas surrounding the discs where growths of the organisms were impeded (Zone of inhibition) were measured in millimeter and recorded. The assay was repeated two more times. The mean and the standard deviation $( \pm S D$ ) for the triplicate values were then calculated.

Table 1: Weights of fractions obtained from the plant samples.

\section{Results and Discussion}

Tables 1-3 Mean of the triplicates \pm S.D (standard deviation). A total ethanolic extract of $16.05 \mathrm{~g}$ was produced from the $200 \mathrm{~g}$ powdered plant sample. The highest percentage mass $(63.05 \%)$ of the total mass macerated was methanol fraction and the least percentage mass $(0.56 \mathrm{~g})$ was the pet. ether fraction. The result of phytochemical analysis revealed the availability of some secondary metabolites in the fractions of the plant sample. The presence of these secondary metabolite's accounts for the activities of the plants. This complied with several reports by researchers that plants contain bioactive substances. Tannins were detected in all the fractions of the plant sample and tannins were reported to have various physiological effects like anti-irritant, anti secretolytic, antiphlogistic, antimicrobial and antiparasitic effect. Phytotherapeutically, tannins containing plants are used to treat non-specific diarrhea, inflammations of mouth and throat and slightly injured skins [20-22]. While cardiac glucosides which are used as lexative and carthatic drugs were confirmed in chloroform and ethyl acetate fractions. Alkaloids that were present in n-hexane and chloroform fractions act as antimalarial and anti-amoebic agents [22]. The antimicrobial sensitivity test result revealed a varied degree of activities exhibited by the fractions of the plant against the test organisms. Although, the plant sample exhibited low activities when compare to the control, the results show that activity of the different fractions may increase further if the concentrations of the fractions were to be increased. The result also showed that the activities of the plant fractions were comparatively more pronounced against E. coli than against S. aureus, S. typhi. and $K$. pneumoniae. With the exception of chloroform fraction that demonstrated some activities against $S$. aureus with zone of inhibition of $12 \mathrm{~mm}$ at $1000 \mathrm{ug} / \mathrm{disc}$ all other fractions were inactive against $S$. aureus. However, n-hexane and ethyl acetate fractions exhibited low activities against $S$. typhi.

\begin{tabular}{|c|c|c|c|c|}
\hline Fractions & Weight(g) & Yield\% & Nature & Colour \\
\hline n- Hexane & 4.51 & 28.15 & Gummy & Yellowish-brown \\
\hline Chloroform & 0.12 & 0.75 & Gummy & Black \\
\hline Ethyl acetate & 1.32 & 8.24 & Oily & Black \\
\hline Methanol & 10.10 & 63.05 & Gummy & Brown \\
\hline
\end{tabular}

Table 2: Some secondary metabolites in the fractions of the plant sample.

\begin{tabular}{|c|c|c|c|c|c|c|}
\hline Fractions & Saponnins & Tannins & Flavonoids & R. sugar & Alkaloids & C. glycosides \\
\hline n- hexane & - & + & + & - & + \\
\hline Chloroform & - & + & - & + & + \\
\hline Ethyl acetate & - & + & - & + & + \\
\hline Methanol & + & + & + & + & - \\
\hline
\end{tabular}


Table 3: Sensitivity test result of the plant sample fractions.

\begin{tabular}{|c|c|c|c|c|c|}
\hline \multirow{2}{*}{ Fractions } & \multirow{2}{*}{ Concentration } & \multicolumn{4}{|c|}{ Zone of Inhibition(mm) } \\
\hline & & S. aureus & E. coli & S. typhi & K. pneumoniae \\
\hline \multirow{5}{*}{ n-Hexane } & 1 & $00.00 \pm 0.00$ & $00.00 \pm 0.00$ & $00.00 \pm 0.00$ & $00.00 \pm 0.00$ \\
\hline & 2 & $00.00 \pm 0.00$ & $09.42 \pm 0.22$ & $00.00 \pm 0.00$ & $00.00 \pm 0.00$ \\
\hline & 5 & $00.00 \pm 0.00$ & $12.15 \pm 0.45$ & $08.76 \pm 0.56$ & $08.66 \pm 0.65$ \\
\hline & 10 & $00.00 \pm 0.00$ & $16.53 \pm 0.32$ & $10.09 \pm 0.42$ & $11.31 \pm 0.66$ \\
\hline & $(+)$ Control & $22.02 \pm 0.33$ & $23.11 \pm 0.21$ & $22.65 \pm 0.33$ & $23.22 \pm 0.44$ \\
\hline \multirow{5}{*}{ Chloroform } & 1 & $00.00 \pm 0.00$ & $00.00 \pm 0.00$ & $00.00 \pm 0.00$ & $00.00 \pm 0.00$ \\
\hline & 2 & $00.00 \pm 0.00$ & $08.09 \pm 0.36$ & $00.00 \pm 0.00$ & $00.00 \pm 0.00$ \\
\hline & 5 & $1076 \pm 0.42$ & $10.77 \pm 0.54$ & $00.00 \pm 0.00$ & $00.00 \pm 0.00$ \\
\hline & 10 & $12.44 \pm 0.28$ & $12.65 \pm 0.52$ & $00.00 \pm 0.00$ & $08.22 \pm 0.73$ \\
\hline & (+) Control & $23.21 \pm 0.22$ & $23.07 \pm 0.32$ & $22.84 \pm 0.24$ & $23.11 \pm 0.36$ \\
\hline \multirow{5}{*}{ Ethyl acetate } & 1 & $00.00 \pm 0.00$ & $00.00 \pm 0.00$ & $00.00 \pm 0.00$ & $00.00 \pm 0.00$ \\
\hline & 2 & $00.00 \pm 0.00$ & $09.30 \pm 0.41$ & $00.00 \pm 0.00$ & $00.00 \pm 0.00$ \\
\hline & 5 & $00.00 \pm 0.00$ & $10.12 \pm 0.55$ & $08.89 \pm 0.3$ & $09.09 \pm 0.42$ \\
\hline & 10 & $00.00 \pm 0.00$ & $12.66 \pm 0.22$ & $10.48 \pm 0.54$ & $11.75 \pm 0.66$ \\
\hline & (+) Control & $22.91 \pm 0.34$ & $23.04 \pm 0.37$ & $22.77 \pm 0.38$ & $23.66 \pm 0.31$ \\
\hline \multirow{5}{*}{ Methanol } & 1 & $00.00 \pm 0.00$ & $09.14 \pm 0.67$ & $00.00 \pm 0.00$ & $00.00 \pm 0.00$ \\
\hline & 2 & $00.00 \pm 0.00$ & $10.87 \pm 0.55$ & $08.33 \pm 0.20$ & $00.00 \pm 0.00$ \\
\hline & 5 & $00.00 \pm 0.00$ & $11.94 \pm 0.24$ & $10.97 \pm 0.31$ & $08.93 \pm 0.47$ \\
\hline & 10 & $00.00 \pm 0.00$ & $13.77 \pm 0.28$ & $12.03 \pm 0.43$ & $10.79 \pm 0.44$ \\
\hline & (+) Control & $22.44 \pm 0.24$ & $23.66 \pm 0.56$ & $22.80 \pm 0.33$ & $22.99 \pm .0 .29$ \\
\hline
\end{tabular}

\section{Conclusion}

The activities of the fractions of the plant sample are more pronounced against $E$. coli than against the other test organisms. $E$. coli can cause diarrhea, urinary tract infections, respiratory illness, bloodstream infections and other illness. So, the plant leaves can be used in the treatment of the aforementioned illnesses. However, the relative low activities of the plant sample fractions against $S$. typhi and K. pneumoniae revealed its un-befitting nature as an antityphoid and anti-pnuemoniie drug.

\section{Recommendation}

The other parts of the plant should also be exploited. To harness its full medicinal potential, the plant sample fractions should be tested against other bacteria isolates and further research should be carried out to isolate and characterize the active compounds in the plant.

\section{References}

1. Joy PP, Thomas J, Samuel M, Baby PS (1998) Medicinal plant: Aromatic and medicinal plants research station, Kerala Agricultural University, India pp.11-13.

2. Erdogrul OT (2002) Antibacterial activity of some plant extracts used as folk medicine. Pharmaceutical Biology 40(4): 269 - 273.

3. Evans CE, Banso A, Samuel OA (2002) Efficiency of some Nupe medicinal plants against salmonella typhi in vitro study. Journal of Ethno Pharmacology 80(1): 21-24.
4. Hill AF (1952) Economic Botany: A textbook of useful plant and plant product $\left(2^{\text {nd }}\right.$ edn.); McGraw Hill bookh company inc New York, USA pp.560.

5. WHO (2008) Traditional medicine.

6. Coates A, Hu Y, Bay R, Page E (2002) The future challenges facing the development of new antimicrobial drugs. Nat bure Review Drug Discovery 1(11): 895-910.

7. Braga LC, Leite AAM, Xavier KGS, Takahasi JA, Bemquerer MP, et al. (2005) Synergic interaction between pomegranate extract and antibiotics against staphylococcus aureaus. Can Journal of Microbiology 51(7): 541- 547.

8. Nuhu H, Abdurrahman EM, Shok M (2009) Ethnomedical studies of crotalaria species found in Zaria. Journal of Pharmacitical science 8(2): 46-53.

9. Polhil RM (1982) Crotalaria in Africa and Madagascar AA Bakema. Royal Botanic Gardens, Kew pp. 195-234.

10. Kow AW, John BJ, Owusu AE (2010) Assessing the effectiveness of the non polar extract of crotalaria retusa in the control and management of the flea beetle, \{Podagrica Uniformis (L)\} on the okro \{Abeslmoschus Esculenhi (L) Moench\}. Journal of Chemical and Pharmaceutical Research 2(4): 387-397.

11. Paul C, Arnold JV, Dirk VB, Louis M (2006) Anti-infective potential of natural product: How to develop a stronger in vitro proof of concept. Journal of Ethnopharmacology 106(9): 290-303.

12. Vaden Barghe DA, Vlietinck AJ (1991) Screening for antibacterial and antiviral agents. In Hostettmann, K Methods, in plant biochemistry. Assay for bioactivity, Academic Press, London, UK 6(3): 47-59.

13. Trease GE, Evan WC (1998) A Textbook of pharmacognosy (11 th edn.); Bailliere Tindall London pp.530. 
14. Wall ME, Krider MM, Krewson CR, Wilaman JJ, Correll SH (1954) Gentty Steroidal Sapogenins XII. Supplementary table of data for steroidal sapogenins vii Agr Research service circ Aic 363: 17.

15. Harbone JB (1973) Phytochemical Methods. Chapman and Hall Ltd, London, UK pp. 49-188.

16. Brain KR, Turner TD (1975) The practical evaluation of phytopharmaceuticals. John Publishers Bristol p. 57-58.

Wright and Sons, Scientetica

17. Bauer AW, Kirby WMM, Sherris JC, Turck M (1966) Antimicrobial susceptibility testing by a standardized single disk method. Am J Clin Pathol 45(4): 493-496.
18. Chesebrough M (1982) Medicinal laboratory manual for tropical countries 31:1862-1867.

19. National Committee for Clinical laboratory Standard (NCCLS) (2000) Performance standard for antimicrobial disk susceptibity test: Approval standard M2/A7 ( $7^{\text {th }}$ edn.); Clinical and Laboratory Standard Institute.

20. Westendarp H (2006) Effects of tannins in animal nutrition. Dtsch Tierarztl Wochenschr 113(7): 264 -208.

21. Trease GE and Evans WC (2000) Pharmalognosy (14 $4^{\text {th }}$ edn.); Harcourt publishers ltd, London pp.612.

22. Abdul G (1990) Introduction to pharmacognosy ( $1^{\text {st }}$ edn.); Ahmadu Bello University Press Ltd, Zaria, Nigeria pp. 187-197.

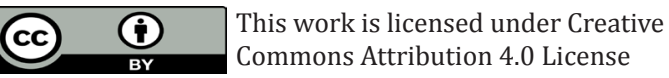

To Submit Your Article Click Here:

Submit Article
DOI: $10.32474 /$ AOICS.2018.03.000173

\section{AOICS}

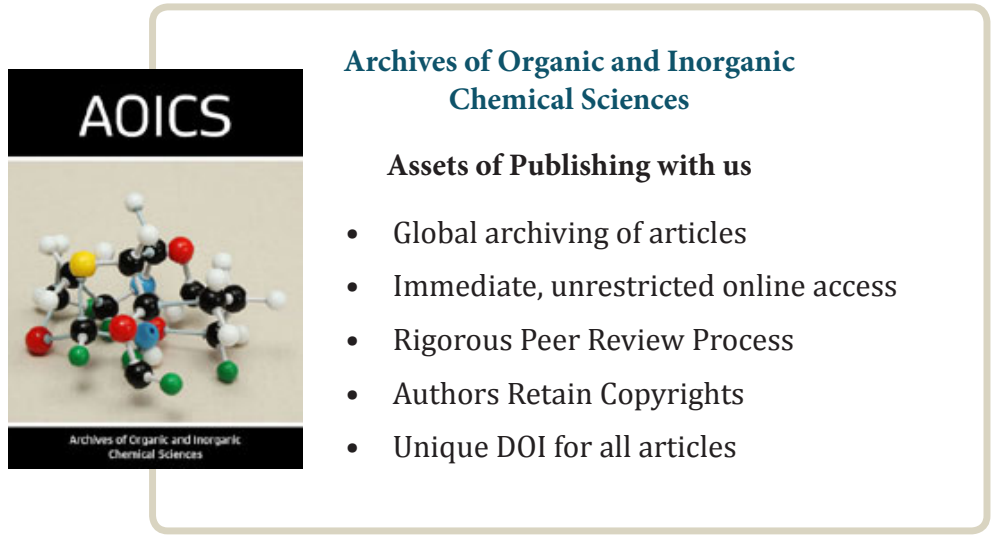

